\title{
Understanding the Importance of Ethical Dilemma with False Confessions
}

\author{
Phillip Neely, Jr. Ph.D. ${ }^{1}$, Amanda Dunstan, BC ${ }^{2}$ \\ ${ }^{1}$ Associate Professor of Criminal Justice, Saint Leo University, USA \\ ${ }^{2}$ Student at Saint Leo University, USA \\ Correspondence: Phillip Neely, Jr., Ph.D., Associate Professor of Criminal Justice, Saint Leo University, USA.
}

Received: August 26, 2018

doi:10.11114/ijce.v1i2.3633

Accepted: September 9, 2018

Online Published: September 17, 2018

URL: https://doi.org/10.11114/ijce.v1i2.3633

\begin{abstract}
The purpose of this article is to gain a better understanding of the ethical dilemma of false confessions that are created from the use of deceptive interrogation tactics. First, this article will explore various types of interrogation tactics that are used by law enforcement and assess those tactics' ability to influence the suspect in providing a false confession. The various interrogatory tactics that are used by law enforcement in the United States will be analyzed, including the deceptive interrogatory tactics used with the Reid-technique model. In addition, alternative interrogatory tactics, such as the PEACE model will be explored, along with assessing the use of the PEACE model tactics on decreasing the chances of false confessions. Secondly, this article will examine the different types of coercion that may be used in an investigation, such as inherent coercion and psychological manipulation. The ethical concerns regarding false confessions and how these confessions can easily be coerced will be examined. Additionally, the risks involved in creating a false memory with suspects during an interrogation will be discussed; consequently, there is a risk of creating a false memory that could lead to a false confession. Furthermore, the Innocence Project and other court cases that involved false confessions will be discussed. Finally, this article will examine a real life story of an innocent child who falsely confessed to the murder.
\end{abstract}

Keywords: Reid-techniques, inherent coercion, psychological manipulation

\section{Introduction}

False confessions are observed by many as a major ethical dilemma for the criminal justice system and it is an issue that needs to be addressed (Abbe \& Brandon, 2013; Banks, 2017; Culhane, Hosch, \& Heck, 2008; Frumkin, 2010; Gudjonsson \& Pearse, 2011; Kassin \& Gudjonsson, 2016; Klaver, Lee, \& Rose, 2008; Lassiter, Meissner, \& American Psychological Association, 2010; Leo, 2008; Vallano, Evans, Schreiber Compo, \& Kieckhaefer, 2015; Vanderhallen, Vervaeke, \& Holmberg, 2011). Many recognize that "false confessions are not a new phenomenon," in that there is an "accumulation of evidence indicating the phenomenon is not as rare as once believed" (Lassiter et al., 2010, p. 50). In addition, false confessions that were led by coerced interrogations have recently become more recognizable due to the use of deceptive interrogatory tactics that are used by investigators (Culhane et al., 2008; Gudjonsson \& Pearse, 2011). According to Culhane et al. (2008), coerced confessions are inadmissible at a court trial due to the increased chance of the confession being false. Williams (2000, as cited in Culhane et al., 2008) states that "although these types of malicious techniques are not a standard for modern interviewing, interrogation practices have continued to come under heavy scrutiny from critics because of the number of false confessions given under psychologically stressful conditions (p. 367). Therefore, it is imperative for interrogators to gain a thorough understanding of the risks involved with deceptive interrogatory tactics; consequently, it is essential to understand the level of coercion and psychological concerns with interrogation tactics to decrease the chances of obtaining a false confession.

\subsection{Police Interviewing Tactics}

Schmalleger (2009) states that interrogation is "the information-gathering of police officers that involves the direct questioning of suspects" (p. 254). In that regard, the concept of interrogation as Schmalleger explains it appears to be simple and direct; however, there is an international debate between what is and is not ethical in regards to the interrogatory tactics that law enforcement use. It is observed that law enforcement use a variety of interrogatory methods that many will find unethical (Abbe \& Brandon, 2013; Gudjonsson \& Pearce, 2011; Vallano, Evans, Schreiber Compo, \& Kieckhaefer, 2015; Vanderhallen, Vervaeke, \& Holmberg, 2011). Nonetheless, as long as the officers are completing the 
interrogation within their course and scope of their job discretion, then they are in compliance with the use of the interrogatory tactics (Banks, 2017). Although, it is argued that law enforcement often use deceptive interrogatory methods when interviewing suspects, in that the use of these deceptive methods could lead to suspects making false confessions (Banks, 2017; Frumkin, 2010; Gudjonsson \& Pearse, 2011; Kassin \& Gudjonsson, 2016; Leo, 2008).

Frumkin (2010) emphasizes that "false confessions occur with some frequency... [in that] the effects of various interrogation methods on the reliability and validity of a confession" can be questioned and could be deemed as unethical (p. 191). It is observed that the most common interrogatory practice in the United States by law enforcement officers is the use of the Reid-technique model (Gudjonsson \& Pearse, 2011; Kassin, Appleby, \& Perillo, 2010; Kassin \& Gudjonsson, 2016; Leo, 2008). Conversely, skeptics suggests that the deceptive tactics used in the Reid-technique model may increase the chances of a suspect providing a false confession; therefore, other interrogatory methods, such as the PEACE model, are recommended to replace the Reid-technique model to reduce the chances of false confessions (Gudjonsson \& Pearse, 2011).

\subsection{Reid-Technique Model}

According to Gudjonsson and Pearse (2011), the Reid-technique model is the most commonly used method of interviewing suspects in American interrogations due to its rate of gained confessions from otherwise non-cooperative suspects. The Reid-technique model uses three primary methods with suspects, in which include the use of isolation, confrontation, and minimization (Gudjonsson \& Pearse, 2011; Kassin \& Gudjonsson, 2016). However, Kassin and Gudjonsson (2016) recognize that "modern police interrogation [is] a guilt-presumptive process of social influence during which trained police use strong, psychologically oriented techniques involving isolation, confrontation, and minimization of blame to elicit confessions" (p. 33).

\subsection{Isolation}

First, in Reid-techniques, the "isolation" method includes the practice of detaining a suspect in isolation, in that "anxiety and uncertainly are generated in order to weaken [the suspect's] resistance" (Gudjonsson \& Pearse, 2011, p. 34). It is observed that isolation is one of the key tactics in the Reid-technique model. However, skeptics of the isolation method will argue that isolation is one of the many deceptive methods that should be considered unethical, due to the potential psychological stress it could cause on the suspect (Culhane, Hosch, \& Heck, 2008).

\subsection{Confrontation-False Evidence}

It is observed that providing false evidence during an interrogation is a highly successful tactic when the suspect is guilty; however, there are concerns that this tactic may cause a non-guilty individual to make a false confession (Banks, 2017; Gudjonsson \& Pearse, 2011; Lassiter \& Meissner, \& American Psychological Association, 2010). First, it is observed that lying may include the investigator telling the suspect that the suspect was observed by a witness committing the crime (Banks, 2017; Lassiter et al., 2010). Secondly, the suspect can also be told that the officers have evidence of the suspect committing the crime, in that the suspect was caught on camera. Thirdly, interrogators can claim that there is evidence to prove that the suspect committed the crime in question; in that interrogators can claim that they have the suspect's fingerprints on the murder weapon. Fourthly, the interrogators can claim that the suspect had failed their polygraph test, when in reality the suspect passed the polygraph test (Banks, 2017).

Even though lying about evidence may appear to be unethical, when lying is done to an extent by an investigator during an interrogation, it does not violate ethical principles (Banks, 2017). In addition, law enforcement are legally allowed to use this type of deception with their interrogation methods. It is debated that if the suspect is not guilty, then the thought process is that the suspect would have nothing to worry about (Banks, 2017; Leo, 2008). Consequently, if the suspect is guilty, then the suspect is more likely to provide incriminating information and admit the suspect's guilt. Although, it should be noted that there are incidences where a suspect who is not guilty will admit their guilt; thus, in those cases, investigators over used their power and abused the extent of the deception used with the suspect. Kassin (2005, as cited in Forrest, Woody, Brady, Batterman, Stastny, \& Burns, 2012) "has hypothesized that an individual may falsely confess when presented with fabricated scientific evidence with the hope that further examination of [the] said evidence will prove the suspect's innocence" (p. 344). Undeniably, historical criminal cases have proven that there are known incidences in which a suspect admitted guilt to a crime that the suspect did not commit; consequently, the interrogators abused their interrogatory methods due to there being no legitimate evidence to support the case besides the suspect's false confession (Banks, 2017; Chambers V. Florida, 2008; Forest et al.; 2012; Schmalleger, 2009).

\subsection{Confrontation- Rejected Denials and Consequences}

As per the Reid-technique model, interrogators are recommended to reject the suspect's repeated claims that the suspect is not guilty of the crime in question; in addition, interrogators are recommended to share with the suspect the possible consequences if the suspect does not admit to committing the crime (Gudjonsson \& Pearse, 2011). Kassin, Appleby, and Perillo (2010) recommend for interrogators "to interrupt all denial efforts should the suspect continue to maintain his or her 
innocence" (p. 42). However, the use of continuing denying the suspect's non-guilty pleas could lead to psychological manipulation and an inherent coerced false confession (Gudjonsson \& Pearse, 2011; Kassin et al., 2010; Leo, 2008; Schmalleger, 2009). Although, Kassin et al. (2010) argue that "a highly confrontational interrogation [is] characterized by the use of persuasive social influence tactics" and that the use of rejecting a non-guilty plea by interrogators is an essential part of the interrogation process (p. 41). Furthermore, after the interrogator as denied the suspect's non-guilty plea multiple times and the interrogator informs the suspect that the suspect will receive the death penalty if they do not tell the truth, but a lesser consequence if they do tell the truth; thus, the suspect may make a false confession that was coerced out of fear of not being viewed innocent and receiving a harsher consequence, such as the death penalty (Nicholas, 2014).

\subsection{Minimization- Gaining the Suspect's Trust}

Gaining the suspect's trust and building a rapport with the suspect during an interrogation may sometimes be the key to obtaining a confession (Abbe \& Brandon, 2013; Gudjonsson \& Pearse, 2011; Lassiter \& Meissner, \& American Psychological Association, 2010; Leo, 2008; Vallano, Evans, Schreiber Comp, \& Kieckhaefer, 2015; Vanderhallen, Vervaeke, \& Holmberg, 2011). Holmberg (2009, as cited in Vanderhallen et al., 2011) states that "rapport can determine whether an interview will fail or succeed" (p. 111). However, it should be noted that in regards to the Reid-technique model, that the use of rapport is primarily used to gain the suspect's trust and cooperation through coercive tactics (Abbe \& Brandon, 2013; Gudjonsson \& Pearce, 2011; Vallano et al., 2015; Vanderhallen et al., 2011). It is observed that interrogators will often try to show sympathy toward the suspect and suggests that the interrogators feel sorry for the suspect (Kassin, Appleby, \& Perillo, 2010; Lassiter et al., 2010). In addition, interrogators will often attempt to create a friendship with the suspect, as an attempt to make the suspect feel more comfortable and more willing to confide the alleged truth to the interrogators (Lassiter et al., 2010).

\subsection{PEACE Model Alternative to the Reid-Technique Model}

Due to the controversial growing concerns of false confessions created with the use of deceptive interrogatory tactics that are consistent with the Reid-technique model, skeptics have suggested the use of the PEACE model as an alternative interrogatory method and as a way to reduce the rate of false confessions (Abbe \& Brandon, 2013; Gudjonsson \& Pearce, 2011; King \& Dunn, 2010). According to Gudjonsson and Pearce (2011), research suggests that with the Reid-technique method that is used with interrogations in the United States, that there is about a $20 \%$ chance that "a small percentage of them, [suspects who confessed, that] could have been innocent" (p. 34). Critics of the Reid-technique model recognize that some tactics that are used in interrogations could be perceived as deceptive; thus, these tactics are concerning because of the increased chance of a coerced false confession (Gudjonsson \& Pearce, 2011; Schmalleger, 2009; Nicholas, 2014).

Supporters of the PEACE model argue that those who are trained in the PEACE model are more prepared to interview guilty and non-guilty suspects (Abbe \& Brandon, 2013; King \& Dunn, 2010). According to King and Dunn (2010), interrogators who are "trained in the Reid-technique, however, were more confident in their ability to detect deception [or the belief that the suspect is lying], in reality, the training decreased their accuracy." It is suggested that interrogators who use deceptive interrogatory tactics, will use those tactics on an innocent suspect; therefore, increasing the chance of influencing the suspect and obtaining a false confession (King \& Dunn, 2010; Gudjonsson \& Pearce, 2011).

The distinction between the Reid-technique model and PEACE model is evident when comparing the use of decreased chances of a false confession and lack of deceptive tactics with the use of the PEACE model (Abbe \& Brandon, 2013; Gudjonsson \& Pearce, 2011; Vallano, Evans, Schreiber Compo, \& Kieckhaefer, 2015; Vanderhallen, Vervaeke, \& Holmberg, 2011). Gudjonsson and Pearce (2011) state that "the PEACE model was developed out of sound psychological principals- following valuable collaborative work between academics, psychologists, police practitioners, and lawyersand was intended to take into account vulnerabilities of some interviewees, with the aim to minimize the risk of false confession[s]" (p. 34). Vallano et al. (2015) argue that the Reid-technique model uses rapport for coercive purposes in obtaining a confession; whereas, the PEACE model uses rapport to build a relationship with the suspect as a traditional method of interrogation. The PEACE model utilizes building a rapport with the suspect during an interrogation as one of the key factors in obtaining a successful confession (Abbe \& Brandon, 2013; Vallano et al., 2015; Vanderhallen et al., 2011). In addition, in regards to the PEACE model, the "police interviewers are not allowed to lie to suspects or present them with false evidence in order to obtain a confession, further reducing the likelihood of a false confession" (Gudjonsson \& Pearce, 2011, p. 34). Thus, the interrogatory tactics used in the PEACE model are drastically different than the tactics that are used with the Reid-technique model.

\section{Discussion of Coercion}

During an interrogation, interrogators will utilize various types of coercion with suspects, in which is consistent with the Reid-techniques that are practiced by most American interrogators (Gudjonsson \& Pearse, 2011; Kassin, Appleby, \& Perillo, 2010; Kassin \& Gudjonsson, 2016; Leo, 2008). However, there are many risks with using coercion during an interrogation. With the use of deceptive interrogatory tactics, skeptics are concerned that these tactics may lead to inherent coercion and 
psychological manipulation; consequently, resulting in a false confession, along with the risk of creating a false memory for the suspect (Gudjonsson \& Pearse, 2011; Kassin et al., 2010; Leo, 2008; Nicholas, 2014; Schmalleger, 2009).

\subsection{Inherent Coercion}

Law enforcement have a history of using inherent coercion during their interrogations. However, this type of coercion is often viewed as an extreme use of interrogatory deception. According to Schmalleger (2009), inherent coercion is "tactics used by police interviewers that fall short of physical abuse but that nonetheless pressure suspects to divulge information" (p. 255). There are many concerns with using inherent coercion during an investigation due to the increased chances of a false confession. It is advisable for interrogators to avoid using inherent coercion to risk the chances of the suspect making a false confession, or making a confession, but have the case dismissed due to concerns of unethical interrogatory deceptive techniques.

In the court cases, Chambers v. Florida (1940) and Ashcraft v. Tennessee (1944), it was observed that the U.S. Supreme Court judges in both of these state cases dismissed the documented confessions by the defendants due to the observed use of inherent coercion during the interrogation (Chambers V. Florida, 2008; Schmalleger, 2009). In 1940, a case decision made for the Chambers v. Florida case resulted in the judge ordering that "the confessions given by the defendants were obtained in violation of the Due Process Clause and therefore, the judgments against them could not stand" (Chambers v. Florida, 2008). It was observed that in this court case, that 4 defendants were going to be given the death penalty as a result of their coerced confessions. In 1944, in the case Ashcraft v. Tennessee, it was observed that the defendant made a coerced confession while interrogators were using tactics, such as shinning bright lights on the defendant, acting kind with offering rewards, and with continuing ongoing interrogation over a 2-3 day time period (Schmalleger, 2009). According to Foster, Davis, and Sandler (1990, as cited in Nicholas, 2014), deceptive interrogation techniques, such as constant interrogation, interrogators providing misleading information, and interrogators offering rewards may be considered forms of "psychological methods of torture;" consequently, increases the chances of a coerced confession that may be false (p. 20).

\subsection{Psychological Manipulation}

In regards to the widely used Reid-techniques that able law enforcement with deceptive tactics in interviewing a suspect, these tactics are oftentimes considered to be psychological manipulators; whereas, these deceptive tactics can lead to psychological manipulation (Gudjonsson \& Pearse, 2011; Klaver, Lee, \& Rose, 2008; Leo, 2008; Schmalleger, 2009). According to Schmalleger (2009), psychological manipulation is "manipulative actions by police interviewers that are designed to pressure suspects to divulge information and that are based on subtle forms of intimidation and control" (p. 255). Klaver et al. (2008) argue that innocent suspects have an increase chance of creating a false confession due to "psychologically manipulative interrogation techniques" (p. 73-74). In addition, Leo (2008) argue that "with the paradigm shift from physical coercion to psychological manipulation, police believe they have been able not only to better shape these confessions so that they will be deemed 'voluntary' and therefore legally admissible" (p. 107). Furthermore, Kassin, Appleby, and Perillo (2010) recognize that the suspect's vulnerability to manipulation varies from suspect to suspect, in that some may be easier to manipulate than other suspects. Therefore, interrogators are cautioned to avoid abusing psychological manipulators, such as lying, tricking, or trying to pressure suspects during interrogations (Gudjonsson \& Pearse, 2011; Kassin et al., 2010; Klaver et al., 2008; Leo, 2008; Schmalleger, 2009).

\subsection{False Memory}

Kassin and Gudjonsson (2016) state that "internalized false confessions are those in which innocent but vulnerable suspects, under the influence of highly suggestive interrogation tactics, come not only to capitulate in their behavior, but also to believe that they committed the crime in question, sometimes confabulating false memoires in the process" (p. 50). Unquestionably, the concept of influencing a suspect's memory to create a new memory and influencing the suspect to believe that the suspect is guilty of crime that they did not commit is unbelievable to many; however, it is a possibility when a suspect is coerced during an interrogation (Goldstein, 2011; Kassin \& Gudjonsson, 2016). Goldstein (2011) states that the misinformation effect includes the concept that "misleading information [is] presented after a person witnesses an event [that] can change how the person describes that event later" (p. 222). In regards to the misinformation effect, it is essential that interrogators do not abuse their wide discretion of deceptive interrogatory tactics, due to the concern that their accusations toward a suspect could cause the suspect to remember the event differently (Goldstein, 2011; Henkel \& Coleman, 2004; Kassin \& Gudjonsson, 2016). According to Goldstein (2011), "the misinformation effect shows not only that false memories can be created by suggestion but also provides an example of how different researchers can interpret the same data in different ways" (p. 223). The concerns with creating false memories due to coerced interrogation tactics is concerning because it leads to false confessions (Henkel \& Coleman, 2004; Goldstein, 2011). Henkel and Coffman (2004) recognize that "suspects can be coerced into falsely confessing to crimes that they did not commit, and in a subset of cases, the confessors come to genuinely believe they committed the crimes and sometimes create vivid 'memories' of their activities" (p. 567). 


\subsection{Other Influential Factors for False Confessions}

In addition, it is essential that interrogators understand that some suspects may be more vulnerable to creating a false confession due to their own level of manipulability and suggestibility (Kassin, Appleby, \& Perillo, 2010; Kassin \& Gudjonsson, 2016; Klaver, Lee, \& Rose, 2008). According to Klaver et al. (2008), there are "several demographic, cognitive, personality, mental health and physiological factors [that] have been indentified theoretically or empirically as relevant to the generation of false confessions" (p. 72). In addition, there are concerns that specific personality types may be more vulnerable to false confessions. Klaver et al. (2008) observed through previous research that mental health and personality traits play a significant role in the suspects increased likelihood of being influenced during an investigation and creating a false confession. Kassin and Gudjonsson (2016) state that individuals with "dispositional tendencies toward compliance and suggestibility, youth, mental retardation, and psychopathology" have an increased chance of making a false confession due to these "personal risk factors for susceptibility" (p. 33). In addition, it is observed in recent studies that there is a significant increase in an individual's ability to make a false confession, due to the individual's willingness to please others (Kassin \& Gudjonsson, 2016; Klaver et al., 2008). Klaver et al., (2008) completed a research study to further investigate the influence of suspects' personality traits and how that impacts their level of suggestibility to provide a false confession. The research suggested "that individuals who have a tendency to change their responses in the face of negative feedback may be more prone to false confession behavior" (Klaver et al., 2008, p. 71).

\subsection{Case Study Examples of False Confessions}

There are many criminal case examples of when a false confession was created based off of unethical interrogation and deceptive investigation methods (Banks, 2017; Kassin, Drizin, Grisso, Gudjonsson, Leo, \& Redlich, 2010; Kassin \& Gudjonsson, 2016). It is observed that there is a history of cases being overturned and the defendants were acquitted for crimes that evidence proved that they did not commit, yet those individuals had made false confessions. Due to the growing concern of wrongfully accused suspects and documented false confessions, it important to explore the innocence project, along with gaining an understanding of how a false confession can be created through a specific case study of the child, Charlie Zubryd-Duffy.

\subsection{The Innocence Project}

The Innocence Project has served as a movement to review previously convicted offenders who may have been convicted due to false confessions, but were exonerated with evidence that proves their innocence (Banks, 2017; Norris, 2014; Schmalleger, 2009). Norris (2017) states that "at the federal level, the 2004 Innocence Protection Act provided standards for DNA testing for potentially innocent prisoners, quality defense in capital cases, and increased federal compensation for the exonerated" (p. 27). In addition, a research study observed that since 1989, that about 15\%-20\% of convicted crime cases involved false confessions and were only exonerated due to DNA (Gudjonsson \& Pearse, 2011, as cited in Kassin, Drizin, Grisso, Gudjonsson, Leo, \& Redlich, 2010, p. 35). According to Kassin and Gudjonsson (2016), "recently, in a number of high-profile cases, defendants who were prosecuted, convicted, and sentenced on the basis of false confessions, have been exonerated through DNA evidence" (p. 33). Some of these most high profiled cases were found with the Innocence Project. Banks (2017) observed concerns with false confessions, in that Banks stated that "the Innocence Project has uncovered many cases in which confessions have been shown to be false and some of these were given in response to police threats that, absent a confession, the accused person would face the death penalty" (p. 93). Using this type of coercion to get a suspect's confession is consistent with the confrontation and promising leniency via minimization tactics that are used with the Reid-technique model (Gudjonsson \& Pearse, 2011; Kopel, 2014; Russano, Meissner, Narchet, \& Kassin, 2005).

\subsection{The Charlie Zubryd-Duffy False Confession}

The murder of Helen Zubryd in 1956, is one of the most known cases involving a false confession that took over 30 years to fully solve. Jim Fisher (1996) observed that the child, Charlie Zubryd-Duffy, was coerced over a two year period by investigators until the child stated that he was guilty and that he murdered his mother. However, the child at the time made a false confession. In addition, the child did not know whether or not he had murdered his mother, even after 30 years had passed. Jim Fisher (1996) initiated an investigation 30 years after the crime had taken place and discovered evidence to prove that the child was innocent. In order to understand how the child made a false confession, it is imperative to have a clear understanding of how the investigators interrogated the child and what deceptive interrogatory tactics were used to coerce the child to make a false confession.

First, the child reported that the detectives claimed that the child's finger prints were on the murder weapon, when in reality there were no distinguishable fingerprints (Fisher, 1996). Undeniably, claiming that law enforcement has a suspect's fingerprints on the weapon is an interrogation tactic that is still used today with law enforcement (Banks, 2017). This method of interrogation is consistent with the claiming false evidence via the confrontation tactic with the Reid-technique model (Banks, 2017; Gudjonsson \& Pearse, 2011; Lassiter \& Meissner, \& American Psychological Association, 2010). At 
this time, claiming that law enforcement have evidence that proves a client is guilty is both a legal and ethically acceptable tactic during an interrogation (Banks, 2017; Kopel, 2014). Therefore, when the detectives told the child that his fingerprints were on the murder weapon, the detectives technical did not make any ethical violations. However, there are a number of ethical concerns with using confrontation tactics with a child; specifically taking into consideration the child's age and mental state of mind due to the concerns of coercion (Gudjonsson, Sigurdsson, Sigfusdottir, Asgeirsdottir, González, \& Young, 2016; Kassin \& Gudjonsson, 2016; Klaver, Lee, \& Rose, 2008).

Secondly, it was reported that the child stated that he did not remember killing his mother, but that the detectives told the child that the child did it (Fisher, 1996). It was observed that the detectives told the child repeatedly over a two year time period that the child murdered his mother. In regards to the Reid-technique model, it is observed that the detectives continued to reject the child's non-guilty pleas until the child finally provided the detectives with a confession. However, Fisher reported that Psychiatrist Dr. William McCabe met with the child after the child had confessed and that Dr. McCabe observed the child for approximately 3 weeks in a hospital. It was reported that after Dr. McCabe completed a full psychiatric evaluation, that Dr. McCabe believed that the child was coerced into making a false confession of murdering the child's mother. Fisher observed that Dr. McCabe was quoted saying the following in regards to the child, "you might say it [the investigation] approached brainwashing that they [the investigators] gave him. You take any intelligent being and keep telling him something over and over again with a promise of a reward at the end and he'll finally comply" (Fisher, 1996, p. 26).

Furthermore, the child reported that after two years of the investigators telling the child that he murdered his mother and that the evidence supported that he did it, that the child began to believe that he actually did it, but had blacked out the event during the murder (Fisher, 1996). It was observed that the details that the child provided in the confession were statements that were suggested to the child by the detectives. Undeniably, with the use of deceptive interrogatory tactics, children are highly susceptible to suggestibility, incoherent coercion, psychological manipulation, false memory, and providing false confessions (Gudjonsson, Sigurdsson, Sigfusdottir, Asgeirsdottir, González, \& Young, 2016; Kassin \& Gudjonsson, 2016; Klaver, Lee, \& Rose, 2008).

\section{Conclusion}

In conclusion, there are many concerns with the validity of confessions obtained with the use of deceptive interrogatory tactics that are commonly used with the Reid-technique model. It is observed that with the use of the Reid-technique model, that there is an increased chance of suspects providing false confessions that may have been created under inherent coercion or psychological manipulation during an interrogation (Gudjonsson \& Pearse, 2011; Klaver, Lee, \& Rose, 2008; Leo, 2008; Nicholas, 2014; Schmalleger, 2009). Gudjonsson and Pearse (2011) offer a recommendation to assist interrogators with decreasing the chances of influencing or encouraging a false confession. According to Gudjonsson and Pearse (2011) "the main challenge for the future is to develop interview techniques that maximize the number of noncoerced true confessions while minimizing the rate of false confessions" (p. 33). In that regard, critics of the Reid-technique model recommend for interrogators to implement the interrogatory tactics that are commonly used in the U.K., the PEACE model, as an alternative to the Reid-technique model (Abbe \& Brandon, 2013; Gudjonsson \& Pearce, 2011; King \& Dunn, 2010; Vallano, Evans, Schreiber Compo, \& Kieckhaefer, 2015; Vanderhallen, Vervaeke, \& Holmberg, 2011).

\section{References}

Abbe, A., \& Brandon, S. (2013). The role of rapport in investigative interviewing: A review. Journal of Investigative Psychology and Offender Profiling, 10(3), 237-249. https://doi.org/10.1002/jip.1386

Banks, C. (2017). Criminal justice ethics: theory and practice. Los Angeles, CA: SAGE.

Chambers, V. F. (2008). In L. J. Palmer, Encyclopedia of capital punishment in the United States (2nd ed.). Jefferson, NC: McFarland. Retrieved from

https://saintleo.idm.oclc.org/login?url=https://search.credoreference.com/content/entry/mcfcpus/chambers_v_florid a/0? institutionId $=796$

Culhane, S., Hosch, H., \& Heck, C. (2008). Interrogation technique endorsement by current law enforcement, future law enforcement, and laypersons. Police Quarterly, 11(3), 366-386. https://doi.org/10.1177/1098611107309116

Evans, J., Houston, K., Meissner, C., Ross, A., LaBianca, J., Woestehoff, S., \& Kleinman, S. (2014). An empirical evaluation of intelligence-gathering interrogation techniques from the united states army field manual. Applied Cognitive Psychology, 28(6), 867-875. https://doi.org/10.1002/acp.3065

Fisher, J. (1996). Fall guys: False confessions and the politics of murder. Carbondale: Southern Illinois University Press.

Forrest, K., Woody, W., Brady, S., Batterman, K., Stastny, B., \& Bruns, J. (2012). False-Evidence ploys and interrogations: Mock jurors' perceptions of false-Evidence ploy type, deception, coercion, and justification. Behavioral Sciences \& the Law, 30(3), 342-364. https://doi.org/10.1002/bsl.1999 
Frumkin, I. B. (2010). Evaluations of competency to waive Miranda rights and coerced or false confessions: Common pitfalls in expert testimony. Police interrogations and false confessions: Current research, practice, and policy recommendations, 191-209. https://doi.org/10.1037/12085-012

Goldstein, E. B. (2011). Cognitive Psychology (3rd ed.). Belmont, CA: Wadsworth, Cengage Learning.

Gudjonsson, G. H., \& Pearse, J. (2011). Suspect Interviews and False Confessions. Current Directions in Psychological Science, 20(1), 33-37. https://doi.org/10.1177/0963721410396824

Gudjonsson, G., Sigurdsson, J., Sigfusdottir, I., Asgeirsdottir, B., González, R., \& Young, S. (2016). A national epidemiological study investigating risk factors for police interrogation and false confession among juveniles and young persons. Social Psychiatry and Psychiatric Epidemiology: The International Journal for Research in Social and Genetic Epidemiology and Mental Health Services, 51(3), 359-367. https://doi.org/10.1007/s00127-015-1145-8

Henkel, L., \& Coffman, K. (2004). Memory distortions in coerced false confessions: A source monitoring framework analysis. Applied Cognitive Psychology, 18(5), 567-588. https://doi.org/10.1002/acp.1026

Kassin, S. (2015). The social psychology of false confessions. Social Issues and Policy Review, 9(1), 25-51. https://doi.org/10.1111/sipr.12009

Kassin, S., \& Gudjonsson, G. (2016). The psychology of confessions. Psychological Science in the Public Interest, 5(2), 33-67. https://doi.org/10.1111/j.1529-1006.2004.00016.x

Kassin, S., Appleby, S., \& Perillo, J. (2010). Interviewing suspects: Practice, science, and future directions. Legal and Criminological Psychology, 15(1), 39-55. https://doi.org/10.1348/135532509X449361

King, W., \& Dunn, T. (2010). Detecting deception in field settings. Policing: An International Journal of Police Strategies \& Management, 33(2), 305-320. https://doi.org/10.1108/13639511011044902

Klaver, J., Lee, Z., \& Rose, V. (2008). Effects of personality, interrogation techniques and plausibility in an experimental false confession paradigm.

Kopel, D. (2014). Miranda is not the Problem: Police Deception Is. Retrieved January 21, 2018, from http://www.davekopel.com/CJ/OpEds/Miranda.htm

Lassiter, G., Meissner, C., \& American Psychological Association. (2010). Police interrogations and false confessions : Current research, practice, and policy recommendations (Decade of behavior). Washington, D.C.: American Psychological Association. https://doi.org/10.1037/12085-000

Leo, R. (2008). Police interrogation and american justice. Cambridge, Mass.: Harvard University Press. https://doi.org/10.4159/9780674033702

Nicholas, L. (2014). Psychological sequelae of political imprisonment during apartheid. South African Journal of Psychology, 44(1), 18-29. https://doi.org/10.1177/0081246313516262

Norris, R. J. (2017). Framing dna: Social movement theory and the foundations of the innocence movement. Journal of Contemporary Criminal Justice, 33(1), 26-42. https://doi.org/10.1177/1043986216673014

Russano, M., Meissner, C., Narchet, F., \& Kassin, S. (2005). Investigating true and false confessions within a novel experimental paradigm. Psychological Science, 16(6), 481-486. https://doi.org/10.1111/j.0956-7976.2005.01560.x

Schmalleger, F. (2009). Criminal justice today: an introductory text for the twenty-first century (10th ed.). Upper Saddle River, NJ, NJ: Prentice Hall.

Vallano, J., Evans, J., Schreiber, C. N., \& Kieckhaefer, J. (2015). Rapport-Building during witness and suspect interviews: A survey of law enforcement. Applied Cognitive Psychology, 29(3), 369-380. https://doi.org/10.1002/acp.3115

Vanderhallen, M., Vervaeke, G., \& Holmberg, U. (2011). Witness and suspect perceptions of working alliance and interviewing style. Journal of Investigative Psychology and Offender Profiling, 8(2), 110-130. https://doi.org/10.1002/jip.138

\section{Copyrights}

Copyright for this article is retained by the author(s), with first publication rights granted to the journal.

This is an open-access article distributed under the terms and conditions of the Creative Commons Attribution license which permits unrestricted use, distribution, and reproduction in any medium, provided the original work is properly cited. 